Agricultural Journal 7 (5): 316-322, 2012

ISSN: $1816-9155$

C) Medwell Journals, 2012

\title{
The Potential Use of Certain Protein Metabolism Parameters as Biomarkers of Heavy Metal (Lead) Stress in the African Catfish, Clarias gariepinus
}

\author{
${ }^{1}$ E.A.A. Olojo, ${ }^{1}$ A.A. Abass, ${ }^{1}$ K.B. Olurin and ${ }^{2}$ G. Mbaka \\ ${ }^{1}$ Department of Plant Science and Applied Zoology, \\ ${ }^{2}$ Department of Anatomy, College of Basic Medical Sciences, \\ Olabisi Onabanjo University, P.M.B. 2002, Ago-Iwoye, Ogun State, Nigeria
}

\begin{abstract}
Some protein metabolism parameters were monitored to assess their potential use as bio-indicators of heavy metal stress in the African catfish Clarias gariepinus. A total 45 adult fishes were treated to continuous exposure of two sub-lethal concentrations of lead $\left(T_{1} 0.006\right.$ and $\left.T_{2} 0.008 \mathrm{mg} \mathrm{L}^{-1}\right)$ for a period of 42 days. The recovery rate was also assessed over a 7 days period in lead free water. The gill and liver tissues were analyzed every 14 days for examination of their protein biochemistry. The parameters analyzed include Total Crude Protein (TCP), Alanine Aminotransaminase (ALT), Aspartate aminotransaminase (AST), Glucomate Dehydrogenase (GDH), Free Ammo Acids (FAA) and ammonia. There was a reduction in the TCP, ALT and GDH in both gill and liver tissues below the control values while the parameters such as ALT, AST, FAA and ammonia in both tissues showed an increment above the control values. The pattern of variation of the protein metabolism parameters of the gill and liver tissues and their recovery were discussed. The effect of lead on protein metabolism parameters showed their potential use as biomarkers in monitoring the level of lead toxicity in the fish.
\end{abstract}

$\underline{\text { Key words: Protein metabolism parameters, potential use, bio-indicators, gill and liver tissues, toxicity }}$

\section{INTRODUCTION}

Lead and environmental compounds water quality guidelines for fresh and marine water are; a maximum of $1-5 \mu \mathrm{g} \mathrm{L}-1$ (i.e., $10^{-6}$ to $5 \times 10^{-6} \mathrm{~g} \mathrm{~L}^{-1}$ ) depending on water hardness for fresh water and for the marine water a maximum of $5 \mu \mathrm{g} \mathrm{L} \mathrm{L}^{-1}$ (i.e., $5 \times 10^{-6} \mathrm{~g} \mathrm{~L}^{-1}$ ) (DWAF, 1996).

Studies have been carried out on the effects of lead contamination on freshwater fish species such as rate of uptake and bioaccumulation (Abdelhamid and El-Ayouty, 1991) haematological and immunological effects (Strivastava and Mishra, 1979; Jana et al., 1986; O'Brien, 2000). However, information on the effect of lead stress on the protein metabolism parameters is scanty.

Proteins are natural polymers made up of $\alpha$-amino acid monomers (Schmid, 1996). These monomer units are condensed into a long polypeptide chain. They constitute that class of biochemical compounds most characteristic of protoplasm and life. They are colloidal, hydrophilic and amphoteric (Kachmar et al., 1992).

Proteins can be classified according to solubility, constitution and physical nature: those that yield only amino acids upon hydrolysis are simple proteins while those that give other products are conjugated proteins (Schmid, 1996). Amino acids have been described as organic amino substituted acids containing amino $\left(-\mathrm{NH}_{2}\right)$ and carboxyl (-COOH) groups (Tewari et al., 2004). Simple amino acids (having only one amino group and carboxyl group) can be classified as: $\alpha, \beta, \gamma$ and $\Delta$-amino acids depending on the position of the amino group with respect to the carboxyl group.

Of these, the $\alpha$-amino acids are the most important as they are the final product of hydrolysis of proteins (Tewari et al., 2004).

Alanine and aspartate transaminases are involved in the deamination of $\alpha$-amino acids in which the amino group is transferred to the $\alpha$-keto-glutarate to yield the $\alpha$-keto-acid of the original amino acid and glutamate. Glutamine or alanine is responsible for the transport of excess ammonia from the muscles to the liver. The process involves glutamine losing its ammonia to regenerate glutamate which in turn is oxidatively deaminated to release ammonia.

Metals are stored in different places in animals depending on the metal and animal species but bioaccumulation occurs primarily in the bones in the liver

Corresponding Author: E.A.A. Olojo, Department of Plant Science and Applied Zoology, Olabisi Onabanjo University, P.M.B. 2002, Ago-Iwoye, Ogun State, Nigeria 
and in the gills. Fishes can regulate metal concentration over a fairly wide range (Bryan, 1976) after which bioaccumulation occurs (Van Der Putte and Part, 1982). The physiological and biochemical differences in species and the position of each tissue are found to influence bioaccumulation (Kotze, 1997).

The effect of heavy metal pollution has been found to be dependent on the nature of the metal (Kachmar et al., 1992), the concentration and duration of exposure (Olojo et al., 2005; Olaifa et al., 2003). Fish exposed to sub-lethal levels of lead showed significant increase in lead concentration in the liver and muscle which was dose- and time-dependent and that the fishes recovered on transfer of fish to lead free water (Jana et al., 1986).

Recovery in fish was faster for those placed under lower concentration of lead than those placed in higher concentration. As such, effects of heavy metal such as lead, on aquatic environment is usually highlighted with respect to their effect on fish (Abdelhamid and El-Ayouty, 1991; Olaifa et al., 2003). Using certain proteins as indices, this study is designed to assess lead stress on C. gariepinus.

\section{MATERIALS AND METHODS}

A to tatal of 36 adult fishes were divided into 6 experimental vats and another 9 fishes were divided into 3 other vats as control all containing fresh water, $\mathrm{pH} 7.7$ for $72 \mathrm{~h}$. Lead $(\mathrm{Pb})$ was introduced directly into the water in form of lead carbonate $\left(\mathrm{PbCO}_{3}\right)$. Two sublethal concentrations were used, $\mathrm{T}_{1}\left(0.006 \mathrm{mg} \mathrm{L}^{-1}\right.$ of $\mathrm{PbCO}_{3}$ and $\mathrm{T}_{2}\left(0.008 \mathrm{mg} \mathrm{L}^{-1}\right.$ of $\left.\mathrm{PbCO}_{3}\right)$ (Bryan, 1976). Nine vats were used, each treatment having three replicates while the last 3 served as the control. For $\mathrm{T}_{1}, 1.2 \mathrm{mg}$ of $\mathrm{PbCO}_{3}$ was weighed using an electronic weighing balance and dissolved in $200 \mathrm{~L}$ of water to give a concentration of $0.006 \mathrm{mgL}^{-1} \mathrm{PbCO}_{3}$. For $\mathrm{T}_{2}, 1.6 \mathrm{mg}$ of $\mathrm{PbCO}_{3}$ was weighed and dissolved in $5 \mathrm{~L}$ of water to give $0.008 \mathrm{mgL}^{-1}$ of $\mathrm{PbCO}_{3}$. Water was changed every 2 weeks with $\mathrm{PbCO}_{3}$ reintroduced to maintain the concentration of the toxicant. Fecal waste was daily removed to maintain the level of dissolved oxygen.

Protein metabolism parameters such as Total Crude Protein (TCP), Alanine Amino Transaminase (ALT), Aspartate Amino Transaminase (AST), Glucomate Dehydrogenase (GDH), Free Amino Acids (FAA) and ammonia were monitored as potential biomarkers of $\mathrm{Pb}$ concentration in the liver and gill tissues of C. gariepinus every 2 weeks. Crude Protein was determined by the method of AOAC (1990) while determination of free
Amino acid was by the method of Barker (1979), ammonia level by Wise (1998) and aminotransaminases by Bates (2001).

\section{RESULTS}

Laboratory analysis of the gill and liver tissues of C. gariepinus exposed to $\mathrm{PbCO}_{3}$ revealed variations in the protein metabolism parameters, viz., total crude protein. Ammonia, free amino acids, alanine and aspartate aminotransaminases along concentration and time gradients.

Total crude protein: Total crude protein of both gill and liver tissues showed lower values than the control in the two treatments $\left(\mathrm{T}_{1}, \mathrm{~T}_{2}\right)$. These values showed a steady decline throughout the experimental period (Fig. 1 and 2). Mean maximum TCP values of $32.90 \pm 0.35$ and $41.18 \pm 0.53$ both in $\mathrm{T}_{1}$ were obtained on day 14 while mean minimum values of $14.82 \pm 0.53$ in $\mathrm{T}_{2}$ and $21.13 \pm 0.55$ in $\mathrm{T}_{1}$ were obtained on day 42 for gill and liver tissues, respectively.

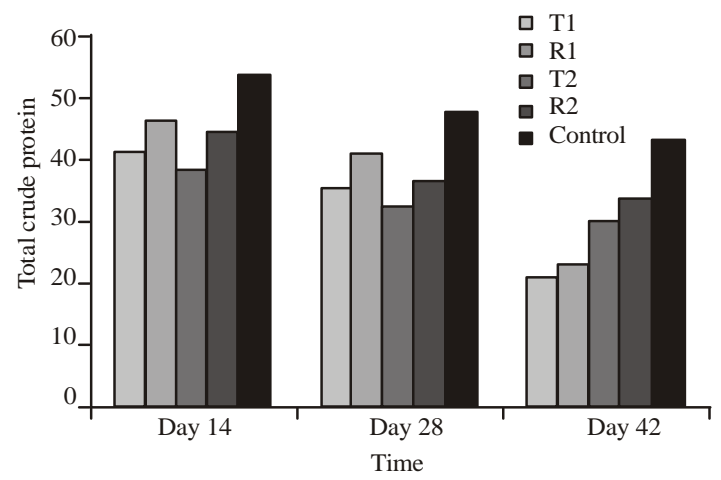

Fig. 1: Changes in total crude protein level in gill of C. gariepinus exposed to two concentrations of lead

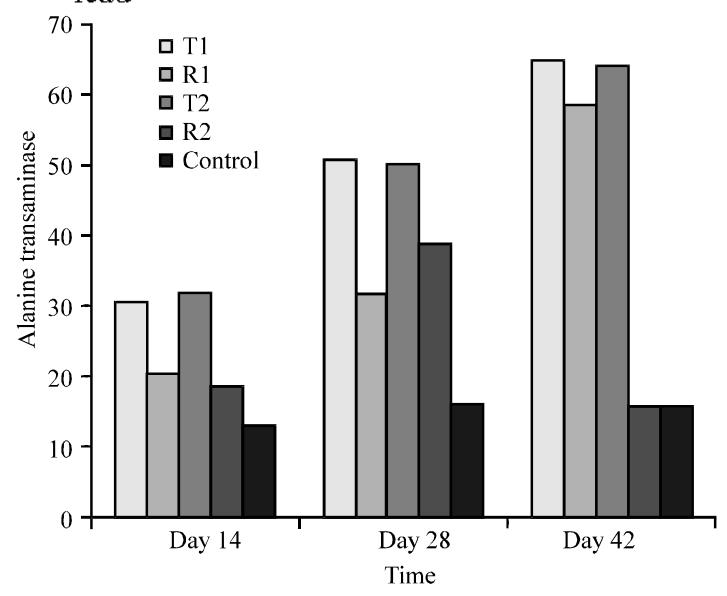

Fig. 2: Changes in alanine transaminase in gill of C. gariepinus exposed to two concentrations of lead 


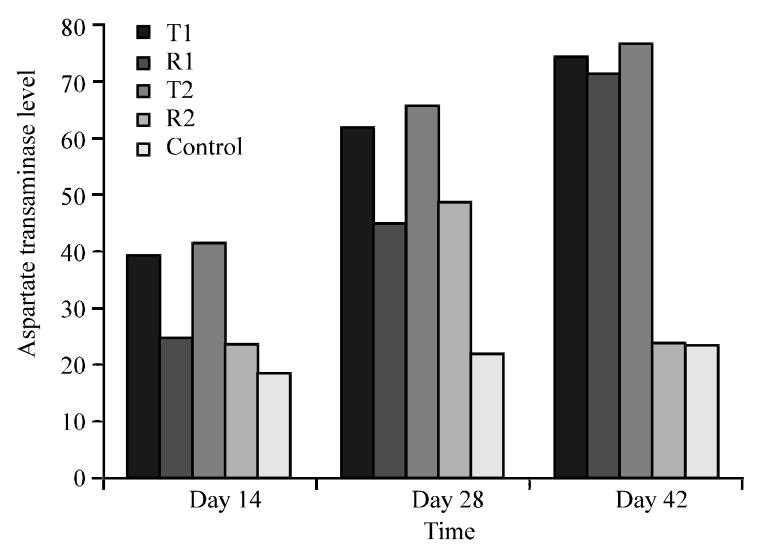

Fig. 3: Changes in aspartate transaminase in gill of C. gariepinus exposed to two concentrations of lead

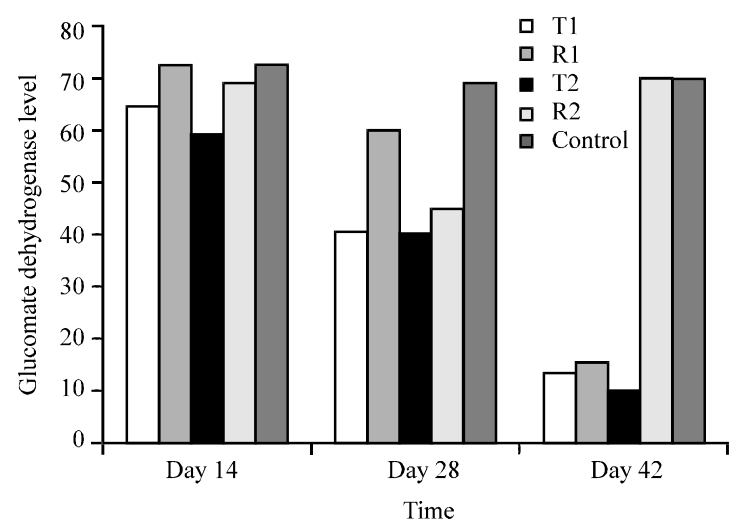

Fig. 4: Changes in glucomate dehydrogenase level in gill of C. gariepinus exposed to two concentrations of lead

Alanine aminotransaminase (ALT): In the gill, lower values of ALT than the control were obtained on day 14 in both treatments $\left(T_{1}\right.$ and $\left.T_{2}\right)$ after which $T_{1}$ showed a steady increase above the control values and $\mathrm{T}_{2}$ a steady decrease below the control the control values (Fig. 3). However, ALT in liver showed a steady increase above the control values both along concentration gradient and time (Fig. 4).

Aspartate aminotransaminase (AST): AST values in both treatments showed considerable consistent increase above the control values in both gill and liver tissues throughout the experimental period (Fig. 5 and 6) with min-max values of $39.33 \pm 1.53$ to $76.00 \pm 3.61$ for gill and $26.33 \pm 1.53$ to $62.67 \pm 2.52$ for liver, respectively.

Glucomate Dehydrogenase (GDH): The GDH levels in gill and liver dropped far below the control level but showed

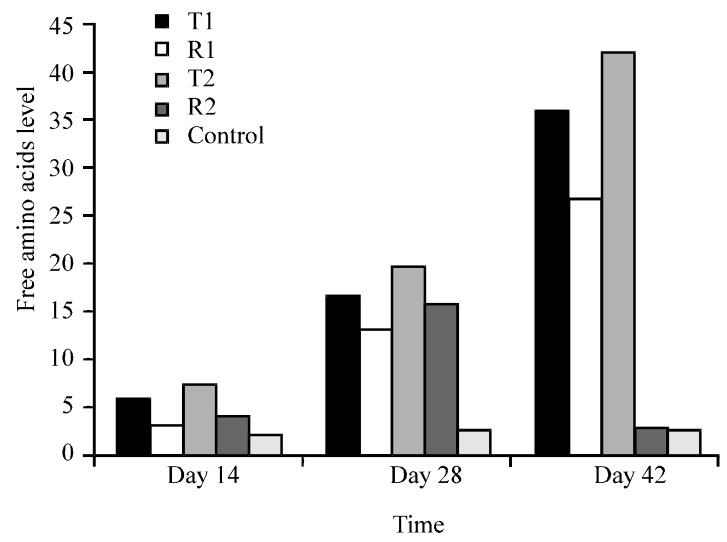

Fig. 5: Changes in free amino acids ileveln gill of C. gariepinus exposed to two concentrations oflead

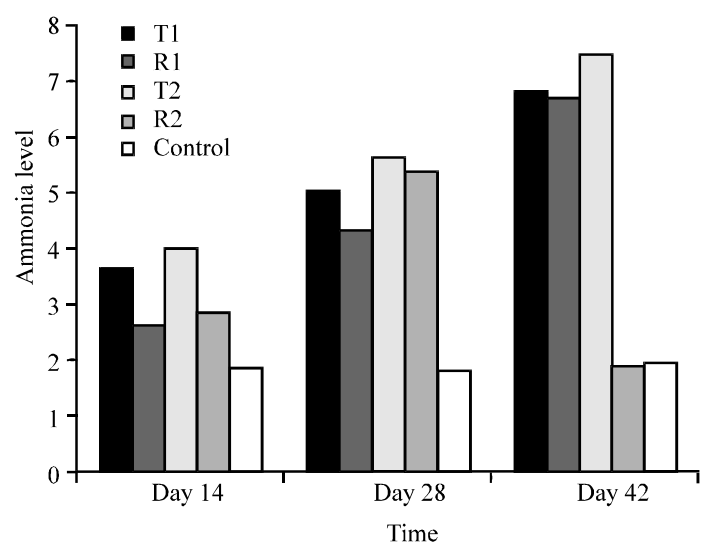

Fig. 6: Changes in ammonia level in gill of C. gariepinus exposed to two concentrations of lead

a consistent increase until day 42 when GDH levels in both $\mathrm{T}_{1}$ and $\mathrm{T}_{2}$ came closest to the control (Fig. 7 and 8). Maximum value of 64.67 and 78.00 were obtained in both gill and liver tissues, respectively (Fig. 8 and 9).

Free Amino Acids (FAA): Production of free amino acids was higher than in the control on day 14 with minimum values of 6.00 and 7.5 in both $T_{1}$ and $T_{2}$ for gill and 5.2 and $7.0 \%$ in liver, respectively which showed a consistent increase to high values ( $36.0 \%$ in $\mathrm{T}_{1}$ and $42.0 \%$ in $\mathrm{T}_{2}$ ) in gill and ( $34.8 \%$ in $\mathrm{T}_{1}$ and $41.5 \%$ in $\mathrm{T}_{2}$ ) on day 42 (Fig. 9 and 10).

Ammonia: Ammonia levels in gill and liver tissues of C. gariepinus in both treatments $\mathrm{T}_{1}$ and $\mathrm{T}_{2}$ recorded higher values than the control on day 14 and showed steady increase throughout the experimental period (Fig. 11 and 12, Table 1 and 2). 
Agric. J., 7 (5): 316-322, 2012

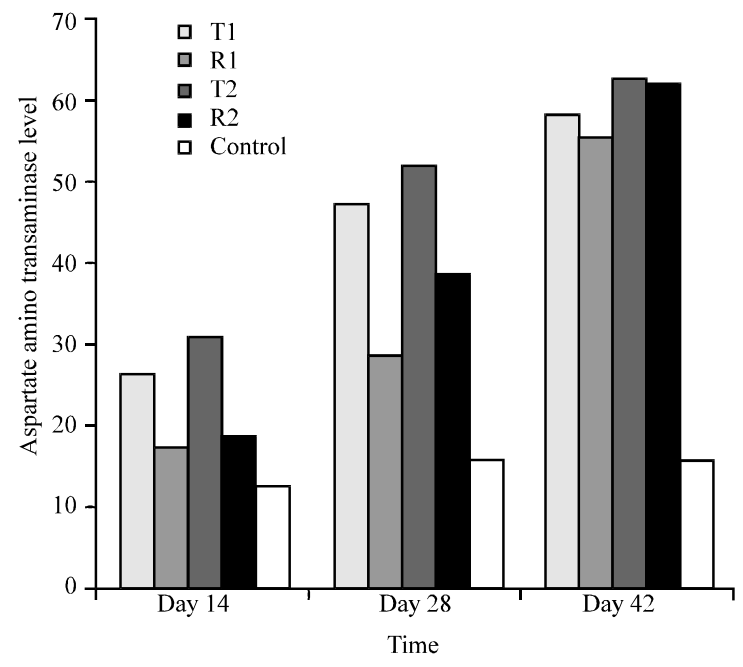

Fig. 7: Changes in aspartate amino transaminase level in liver of C. gariepinus exposed to two concentrations of lead

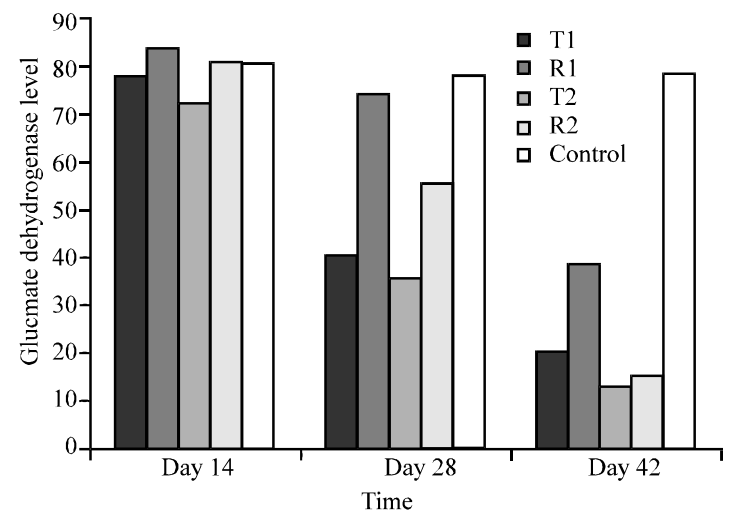

Fig. 8: Changes in glucomate dehydrogenase level in liver of C. gariepinus exposed to two concentrations of lead

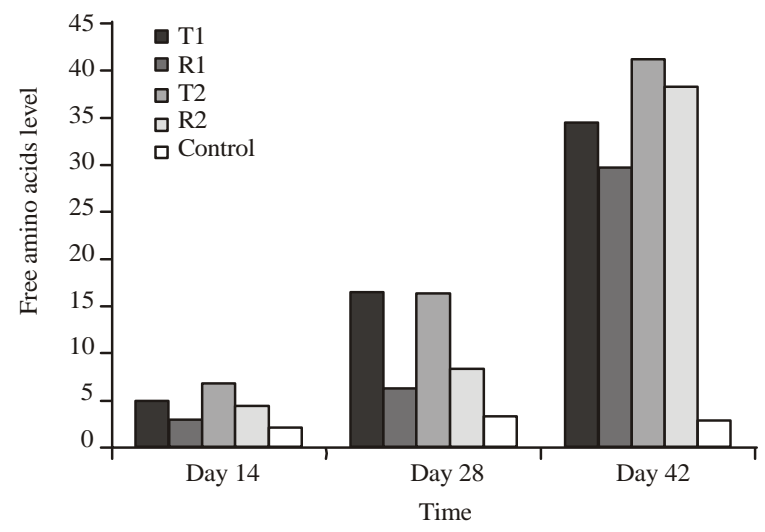

Fig. 9: Changes in free amino acids level in liver of C. gariepinus exposed to two concentrations of lead

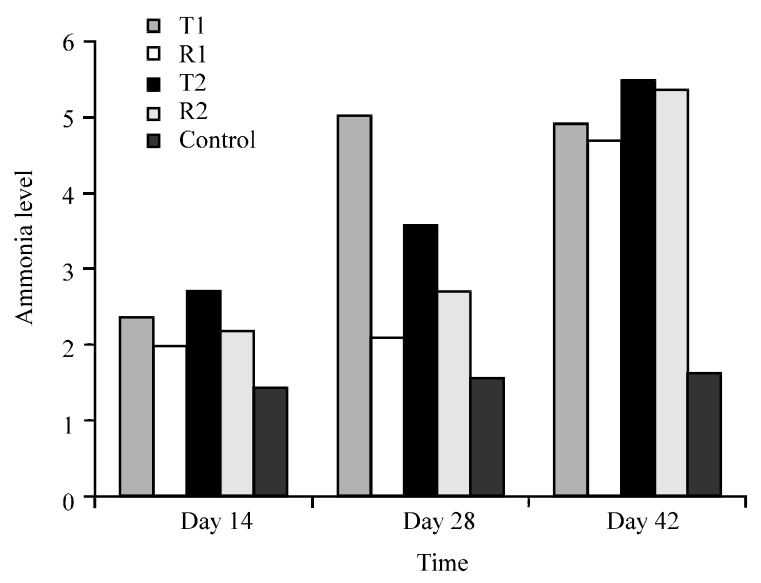

Fig. 10: Changes in ammonia level in liver of C. gariepinus exposed to two concentration of lead

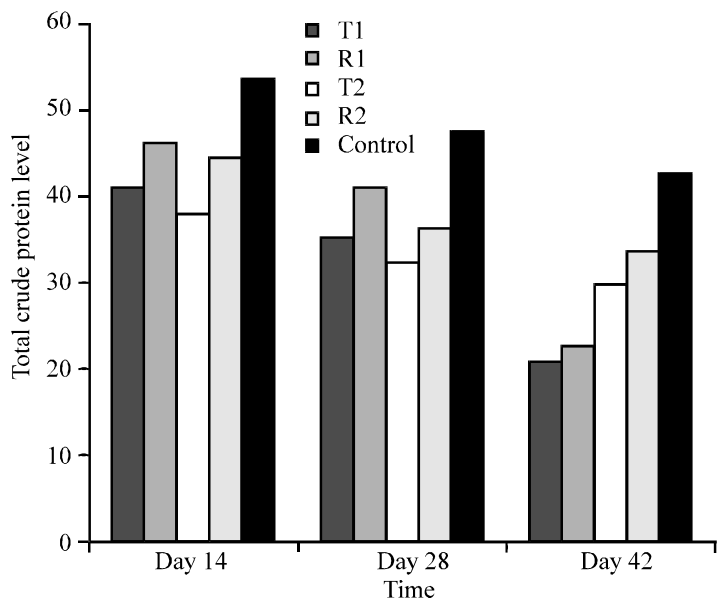

Fig. 11: Changes in total crude protein level in liver of C. gariepinus exposed to two concentrations of lead

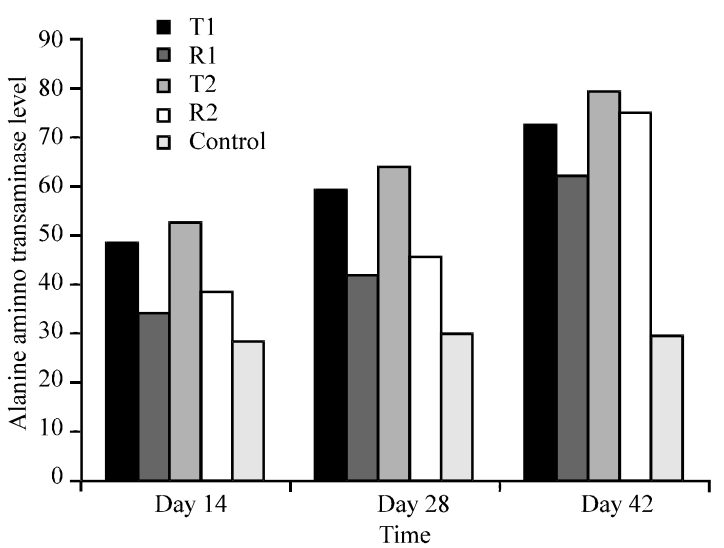

Fig. 12: Changes in alanine aminnotransaminase level in liver of C. gariepinus exposed to two concentrations of lead 
Agric.J., 7 (5): 316-322, 2012

Table 1: The mean, standard deviation, minimum and maximum values of the gill analysis for day 14 Gill

\begin{tabular}{|c|c|c|c|c|c|c|}
\hline Time (day 14) & TCP & $\mathrm{ALT}$ & AST & GLU & FAA & AMM \\
\hline $\mathrm{C}(\mathrm{X} \pm \mathrm{SD})$ & $46.00 \pm 0.53$ & $13.00 \pm 2.00$ & $18.33 \pm 1.53$ & $72.33 \pm 1.53$ & $1.93 \pm 0.10$ & $1.88 \pm 0.35$ \\
\hline Min-Max & $45.50-46.55$ & $11.00-15.00$ & $17.00-20.00$ & $71.00-74.00$ & $1.87-2.05$ & $1.84-1.90$ \\
\hline $\mathrm{Tl}(\mathrm{x} \pm \mathrm{SD})$ & $32.90 \pm 0.35$ & $30.33 \pm 1.53$ & $39.33 \pm 1.53$ & $64.67 \pm 1.53$ & $5.98 \pm 0.28$ & $3.63 \pm 0.17$ \\
\hline Min-Max & $32.55-33.25$ & $29.00-32.00$ & $38.00-41.00$ & $63.00-66.00$ & $5.79-6.30$ & $3.47-3.81$ \\
\hline $\mathrm{Rl}(\mathrm{x} \pm \mathrm{SD})$ & $38.62 \pm 0.53$ & $20.33 \pm 2.08$ & $24.33 \pm 2.08$ & $72.33 \pm 3.06$ & $3.12 \pm 0.39$ & $2.63 \pm 1: 0.10$ \\
\hline Min-Max & $38.15-39.20$ & $18.00-22.00$ & $22.00-26.00$ & $69.00-75.00$ & $2.72-3.49$ & $2.52-2.72$ \\
\hline $\mathrm{T} 2(\mathrm{x} \pm \mathrm{SD})$ & $29.17 \pm 1.13$ & $31.67 \pm 2.08$ & $41.67 \pm 1.53$ & $59.00 \pm 1.00$ & $7.3 \pm 0.93$ & $4.01 \pm 0.70$ \\
\hline Min-Max & $28.35-30.45$ & $30.00-34.00$ & $40.00-43.00$ & $58.00-60.00$ & $6.25-7.96$ & $3.94-4.08$ \\
\hline $\mathrm{R} 2(\mathrm{X} \pm \mathrm{SD})$ & $33.72 \pm 0.53$ & $18.67 \pm 1.53$ & $23.33 \pm 0.58$ & $68.67 \pm 2.08$ & $4.14 \pm 0.48$ & $2.86 \pm 0.07$ \\
\hline Min-Max & $33.25-34.30$ & $17.00-20.00$ & $23.00-24.00$ & $67.00-71.00$ & $3.61-4.53$ & $2.79-2.92$ \\
\hline
\end{tabular}

Table 2: The mean, standard deviation, minimum and maximum values of the gill analysis for day 28 Gill

\begin{tabular}{|c|c|c|c|c|c|c|}
\hline Time (day 28) & TCP & ALT & AST & GLU & FAA & AMM \\
\hline $\mathrm{C}(\mathrm{x} \pm \mathrm{SD})$ & $43.17 \pm 0.53$ & $16.00 \pm 2.00$ & $21.67 \pm 1.53$ & $68.67 \pm 1.53$ & $2.72 \pm 0.36$ & $1.83 \pm 0.18$ \\
\hline Min-Max & $42.70-43.75$ & $14.00-18.00$ & $20.00-23.00$ & $60.00-67.00$ & $2.39-3.10$ & $1.63-1.97$ \\
\hline $\mathrm{Tl}(\mathrm{x} \pm \mathrm{SD})$ & $26.02 \pm 0.73$ & $50.67 \pm 1.53$ & $61.67 \pm 1.53$ & $40.33 \pm 3.06$ & $16.60 \pm 0.82$ & $5.01 \pm 0.10$ \\
\hline Min-Max & $25.20-26.60$ & $49.00-52.00$ & $60.00-63.00$ & $37.00-43.00$ & $15.75-17.38$ & $4.90-5.10$ \\
\hline $\mathrm{Rl}(\mathrm{x} \pm \mathrm{SD})$ & $28.00 \pm 0.35$ & $31.67 \pm 11.53$ & $44.67 \pm 1.53$ & $60.00 \pm 2.00$ & $13.14 \pm 0.26$ & $4.31 \pm 0.21$ \\
\hline Min-Max & $27.65-28.35$ & $30.00-33.00$ & $43.00-46.00$ & $58.00-62.00$ & $12.92-13.43$ & $4.08-4.49$ \\
\hline $\mathrm{T} 2(\mathrm{x} \pm \mathrm{SD})$ & $24.03 \pm 0.53$ & $50.00 \pm 1.00$ & $65.33 \pm 1.53$ & $24.33 \pm 2.08$ & $19.68 \pm 0.90$ & $5.64 \pm 0.65$ \\
\hline Min-Max & $23.45-24.50$ & $49.00-51.00$ & $64.00-67.00$ & $22.00-26.00$ & $18.65-20.30$ & $5.58-5.71$ \\
\hline $\mathrm{R} 2(\mathrm{X} \pm \mathrm{SD})$ & $26.25 \pm 0.70$ & $38.67 \pm 0.58$ & $48.67 \pm 1.53$ & $45.00 \pm 2.00$ & $15.74 \pm 1.16$ & $5.37 \pm 0.70$ \\
\hline Min-Max & $25.55-26.95$ & $38.00-39.00$ & $47.00-50.00$ & $43.00-47.00$ & $14.48-16.77$ & $5.30-5.44$ \\
\hline
\end{tabular}

\section{DISCUSSION}

Total Crude Protein (TCP): The decline in TCP levels reported in this research could be attributed to protein denaturation which is caused by heavy metals (cations) especially lead. $\mathrm{Pb}$ is known to form strong bonds with the negatively charged carboxyl groups on the alkyl groups of proteins, thus disrupting its ionic bonds. This reduces the protein's electrical polarity and thus increases its solubility. This causes the protein to precipitate out of solution (Taylor, 2005). $\mathrm{Pb}$ has also been reported to stimulate gluconeogenesis, whereby crude protein is converted into glycogen and that lead-contaminated fishes are initially low on glycogen (Yun, 2004; Davies et al., 2003). Pb has been reported to cause inhibition of protein synthesis thereby reducing the TCP over time and with increasing concentration, this is done by preventing the formation of sulphur bridges which hold the amino acids together in a polypeptide chain during translation, thus giving it its primary structure (Mommsen and Walsh, 1992). It has been reported that damage to hepatocyte cells of the liver also stalls the process of protein synthesis as it functions in protein synthesis of proteins such as glucoprotein, serum albumin, glycoprotein, cerruplasmin, lipoprotein and others (Olojo et al., 2005). The observed greater percentage drop in TCP in the gills compared to the liver could be attributed to the detoxification of contaminants in the liver by the hepatocyte and the liver being the biochemical hub of the body of the fish while the higher percentage drop in TCP at day 42 in both gill and liver tissues is due to the damage done by the build-up of $\mathrm{Pb}$ in the fish. Begun (2004) earlier observed a delayed decrease in the TCP in the liver of Clarias batrachus treated with carbofuran insecticide which recovered when placed in lead free water. Also, a significant reduction in TCP has been observed in C. gariepinus exposed to $\mathrm{PbCl}$ (Abdelhamid and El-Ayouty, 1991) as well as Oreochromis mossambicus treated with $\mathrm{PbS}(\mathrm{O}$ 'Brien, 2000). However, this report is in contrast with the report of Jana et al. (1986) who observed an increase in TCP in the liver relative to the control values when C. batrachus was treated with lead.

Alanine and Aspartate transaminases (ALT and AST): The observed elevated levels of both ALT and AST have been reported to be associated with damage to the gill and liver tissues by heavy metals such as lead (Jiraungkoorskul et al., 2003). This trend could also be as a result of conformational changes contributing to the catalytic activity of the enzymes which is enabled by the opening up of an active site that is otherwise closed. Inorganic ions such as $\mathrm{Pb}^{2+}$ have been reported to activate enzymes by molding either the enzyme or the substrate into a shape that allows the enzyme or the substrate to be formed again (Taylor, 2005). It is being known that the increase in such enzyme activators stimulates an increase in the enzyme secretion. The earlier 
structural damages to the gill and liver tissues due to exposure to lead have been reported to be significantly correlated $(p<0.05)$ to the increase in the enzymes secretion resulting in biochemical alteration in the fish (Jiraungkoorskul et al., 2003).

Glucomate Dehydrogenase (GDH): The observed elevation of GDH in this study has also been reported by Saha et al. (2000) who observed an increase in GDH in the ammonia-forming direction (Begun, 2004) on C. batrachus contamination by carbofuran insecticide while Kelly and Stanley (2001) report on the effect of $\mathrm{PbCl}_{2}$ on $O$. nilotica revealed similar trends as a result of lead contamination. According to McKee and McKee (1996), this could be as a result of the increase in Glutamate (GLU) substrate production due to the increased activities of ALT and AST converting alanine and aspartate respectively:

- $\quad$ Alanine $+\alpha$-keto-glutarate $---\rightarrow$ pyruvate + glutamate

- Aspartate $+\alpha$-keto-glutarate $\leftarrow--\rightarrow$ oxaloacetate + glutamate

- Glutamate plays an important role in the body's disposal of excess or waste nitrogen. Glutamate undergoes deamination, an oxidative reaction catalyzed by GDH

- Glutamate + water $\mathrm{NAD}^{-} \rightarrow--\alpha$-keto-glutarate + $\mathrm{NADH}^{-}+$ammonia $+\mathrm{H}^{+}$

Or when glutamate transports NAD from the gill in form of Glutamine (GLU) to the liver where it frees $\mathrm{NH}^{+}$ from the GLN to regenerate GLU for oxidative deamination to release ammonia.

Free Amino Acids (FAA): The increase in the Free Amino Acids (FAA) level observed in this study has earlier being reported by Jana et al. (1986) and Saha et al. (2000) who noted a significant increase in the FAA in the liver of C. batrachus and Clarias gariepinus, respectively as a result of lead exposure, leading to the efflux of FAA into the blood. This elevation in FAA levels could be attributed to the increase in levels of ALT and AST. By transamination, ALT and AST produce more FAA in the fish. GDH is physiologically significant in amino acids metabolism and as such, the increase in GDH would lead to an increase in FAA (Moyes et al., 1985). The observed inhibition of protein synthesis by $\mathrm{Pb}$ in this research also allows for a build-up of FAA in the fish.

Ammonia: The observed increase in ammonia levels reported in this research could be attributed to the fact that increased activities of the enzymes ALT and AST resulted in increased glutamine and glutamate production as a result of the breakdown of crude protein into amino acids with the generation of nitrogenous wastes. Increased levels of ammonia could also be due to the elevated GDH activity in the fish in terms of amino acids metabolism. Similar report was given by Saha et al. (2000) who observed an increase in GDH in the ammonia forming direction. The higher rise in ammonia level in gill compared to liver is as a result of detoxification by the hepatocyte cells of the liver and also due to the increased diffusion distance between blood and water in the gill due to damage (Mary, 2004). This consequently increases the gill ammonia concentration, damaging the gill the more in a positive feedback reaction.

\section{CONCLUSION}

Protein metabolism parameters exhibit varying degree of changes when subjected to different factors such as heat and metal toxicity. The changes in six proteins of fish under lead toxicity reported in this study suggests that these protein metabolism parameters such as total crude protein, alanine and aspartate aminotransaminases, glucomate dehydrogenase, ammonia and free amino acids, can be used as potential biomarkers of lead toxicity in C. gariepinus.

\section{REFERENCES}

AOAC, 1990. Official Methods of Analysis of the Association of Official Analytical Chemists. 15th Edn., AOAC, Arlington, Virginia, USA., Pages: 550.

Abdelhamid and El-Ayouty, 1991. Effect of lead chloride on C. gariepinus. Department of Fish and Poultry Production. Faculty of Agriculture, Mansoura University, Egypt.

Barker, R.J., 1979. Karyology. In: Biology of Bats of the New World Family Phyllostomatidae, Baker, R.J., J.K. Jones Jr. and D.C. Carter (Eds.). Museum Publications, Philadelphia, PA, USA., pp: 107-156.

Bates, G.M., 2001. Characterization of the protein component of Methanococcus jannaschii RNase P. M.S. Thesis, North Carolina State University, Raleigh, NC, USA.

Begun, G., 2004. Carbofuran insecticide induced biochemical alternation in liver and muscles tissues of fish Clarias batrachus (Linn) and recovery response. Aquat. Toxicol., 66: 83-92.

Bryan, G.W., 1976. Heavy Metal Contamination in the Sea. In: Marine Pollution, Johnston, R. (Ed.). London Academic Press, London, pp: 185-302.

DWAF, 1996. South African water quality guidelines. J. Aquatic Ecosyst., 7: 124-163. 
Davies, B.A., J.D. Topp, A.J. Sfeir, D.J. Katzmann and D.S. Carney et al., 2003. Vps9p CUE domain ubiquitin binding is required for efficient endocytic protein traffic. J. Biol. Chem., 278: 19826-19833.

Jana, F., J. Yuan and H. Cook, 1986. Effect of lead contamination on the liver of Clarias batrachus. J. Aquatic. Zool., 26: 20-22.

Jiraungkoorskul, W., E.S. Upatham, M. Kruatrachue, S. Sahaphong, S. Vichasri-Grams and $P$. Pokethitiyook, 2003. Biochemical and histopathological effects of glyphosate herbicide on Nile tilapia (Oreochromis niloticus). Environ. Toxicol., 18: 260-267.

Kachmar, D., F. Stent and S. Edinburgh, 1992. Fundamentals of Aquatic Toxicology: Methods and Application. Hemisphere Publishing Corporation, New York, USA., pp: 124-163.

Kelly, A. and C.A. Stanley, 2001. Disorders of glutamate metabolism. Mental Retard. Dev. Disabil. Res. Rev., 7: 287-295.

Kotze, P.J., 1997. Aspect of water metal contamination of sediment and fish in the Olifant River, Mpumalanga. M.Sc. Thesis, Rand Afrikaans University, South Africa.

Mary, A.T., 2004. Effect of heavy metals on the gill of teleost. Vet. Haematol. Publ., 41: 61-64.

McKee, T. and J. McKee, 1996. Biochemistry: The Molecular Basis ofLife. 3rdEdn., McGraw-Hill, USA., pp: 43.

Mommsen, T.P. and P.J. Walsh, 1992. Biochemical and environmental perspectives on nitrogen metabolism in fishes. Cell. Mol. Life Sci., 48: 583-593.

Moyes, C.D., T.W. Moon and J.S. Ballantyne, 1985. Glutamate catabolism in mitochondria from $M y a$ arenaria mantle: Effects of $\mathrm{pH}$ on the role of glutamate dehydrogenase. J. Exp. Zool., 236: 293-301.
Olaifa, F.E., A.K. Olaifa and O.O. lewis, 2003. Toxic stress of lead on Clarias gariepinus (African catfish) fingerlings. Afr. J. Biomed. Res., 6: 101-104.

Olojo, E.A.A., K.B. Olurin, G. Mbaka and A.D. Oluwemimo, 2005. Histopathology of the gill and liver tissues of the African catfish Clarias gariepinus exposed to lead. Afr. J. Biotechnol., 4: 117-122.

O'Brien, T., 2000. Histopathological effect of lead sulphide on the liver of Oreochromis mossambicus. Aquatic J. Zool., 5: 11-15.

Saha, N., S. Dutta and D. Haussinger, 2000. Changes in free amino acid synthesis in the perfused liver of an air-breathing walking catfish, Clarias batrachus infused with ammonium chloride: A strategy to adapt under hyperammonia stress. J. Exp. Zool., 286: 13-23.

Schmid, G.H., 1996. Organic Chemistry. Mosby-Year Book, St. Louis, MO, USA., ISBN: 13-9780801674907, pp: 62.

Strivastava, A.K. and S. Mishra, 1979. Blood dyscrasia in a teleost, Colisa fasciatus after acute exposure to sub-lethal concentration of lead. J. Fish Biol., 14: 199-203.

Taylor, E., 2005. Fundamentals of aquatic toxicology: Methods and application. J. Aquatic Toxicol., 2: $18-20$.

Tewari, K.S., N.K. Vishnoi and S.N. Mehrotra, 2004. A Textbook of Organic Chemistry. 3rd Edn., Prentice Hall, New Jersey, USA., pp: 637.

Van Der Putte, I. and P. Part, 1982. Oxygen and chromium transfer in perfused gills of rainbow trout (Salmo gairdneri) exposed to hexavalent chromium at two different $\mathrm{pH}$ levels. Aquatic Toxicol., 2: 31-45.

Wise, R.A., 1998. Drug-activation of brain reward pathways. Drug Alcohol Depend., 51: 13-22.

Yun, 2004. Aspects of fish physiology in relation to their pollution: Effect of lead on the gill, bone and liver of C. gariepinus. J. Urban Environ. Sci., 11: 283-286. 